\title{
Transformacja uniwersytetu. „Kultury audytu” i neoliberalne technologie zarządzania podmiotami społecznymi²
}

\begin{abstract}
The article focuses on the changes in the field of higher education which have occurred during the period of systemic transformation in Poland; particularly on the influence of the regulations introduced in 2011. Following Cris Shore and Susan Wright the author argues that reforms are not only routine, bureaucratic practices but they have a profound impact on social life. In the light of this claim she suggests that the new law not only enforced structural adjustments in the academia but also triggered the process of reshaping the idea of university itself. This shift can be explained in terms of neoliberalisation (in the Foucauldian sense), as the process of transforming academia into the institution driven and dominated by the discourses of efficiency. In order to achieve that goal various tools developed for measuring academic and teaching performance, assessing research quality and institutional effectiveness were introduced. The author
\end{abstract}

1 Marta Songin-Mokrzan, Instytut Etnologii i Antropologii Kulturowej, Uniwersytet Łódzki, Polska, martasongin@gmail.com.

2 Prowadzone przeze mnie badania nad neoliberalizmem (projekt badawczy zatytułowany: Specjalna Strefa Ekonomiczna jako przestrzeń realizacji „neoliberalnego imaginarium”) zostały sfinansowane ze środków Narodowego Centrum Nauki przyznanych w ramach finansowania stażu po uzyskaniu stopnia naukowego doktora na podstawie decyzji numer DEC-2013/08/S/HS3/00271. 
pays particular attention to practices of auditing, also defined as 'rituals of verification', which play a significant role in the process of producing accountable, self-disciplined and calculative neoliberal subjects.

\section{Key words:}

higher education, neoliberalism, politics, neoliberal subject, audit culture

Celem artykułu jest namysł nad zmianami zachodzącymi w obszarze szkolnictwa wyższego w Polsce po roku 1989. W szczególności interesować mnie będzie proces konstruowania nowej idei uniwersytetu, który idzie w parze z przekształceniami prawnymi i instytucjonalnymi dokonującymi się na gruncie akademickim na przestrzeni ostatnich dwóch dekad ${ }^{3}$. Moja uwaga koncentrować się będzie w głównej mierze na ustawie wprowadzonej przez Ministerstwo Nauki i Szkolnictwa Wyższego w 2011 roku$^{4}$. Chciałabym zastanowić się nad tym, jaki obraz uniwersytetu wyłania się wraz z postępującą transformacją tej instytucji? Jak zmienia się myślenie o uniwersytecie, jego zadaniach i celach w wyniku wprowadzania regulacji prawnych (tj. ustaw, aktów i rozporządzeń). Za Crisem Shorem i Suzan Wright uznaję jednocześnie, że owe „na pozór nudne, rutynowe i biurokratyczne praktyki wywierają często głęboki wpływ na życie społeczne”, wiążą się z wykształceniem nowego języka, norm, etyki i polityk zarządzania (Shore, Wright, 2000, s. 57-60).

Zmiany, jakie zaszły w ostatnim dwudziestoleciu w obszarze szkolnictwa wyższego w Polsce, są zarówno efektem transformacji systemowej oraz towarzyszących jej procesów globalizacyjnych, jak i przystąpienia Polski do Unii Europejskiej. Za najważniejsze z nich uznaje się: 1) gwałtowny wzrost liczby studentów, powodowany zarówno wejściem w dorosłe życie pokolenia wyżu demograficznego przełomu lat 70./80. XX wieku, jak i koniecznością podnoszenia własnych kwalifikacji zawodowych w obliczu nowych wymogów stawianych przez pracodawców oraz 2) zwiększenie liczby szkół wyższych, w tym głównie uczelni niepublicznych ${ }^{5}$. Powszechnie przyjmuje się, że zjawiskom tym, które ściśle

3 Pojęciem uniwersytetu posługuję się tu nie w celu denotacji określonego typu wyższej uczelni. Pełni ono tutaj funkcję metonimii, która odnosi się do pewnej usankcjonowanej tradycją idei kształcenia i rozumienia nauki.

4 Ustawa z dnia 18 marca 2011 r. o zmianie ustawy - Prawo o szkolnictwie wyższym, ustawy o stopniach naukowych i tytule naukowym oraz o stopniach i tytule w zakresie sztuki oraz o zmianie niektórych innych ustaw (Dz.U. $2011 \mathrm{nr} 84$ poz. 455).

5 Według danych GUS liczba ta zwiększyła się od 92 uczelni w roku 1989 do 460 w roku 2011, 
powiązane są z wprowadzaniem mechanizmów rynkowych w obszarze szkolnictwa wyższego, towarzyszyło podniesienie konkurencyjności pomiędzy poszczególnymi ośrodkami akademickimi, a w konsekwencji zróżnicowanie oferty edukacyjnej oraz poziomów nauczania. Jednocześnie podjęte zostały działania reformatorskie, których celem jest przeciwdziałanie negatywnym skutkom procesów transformacyjnych oraz rekonstrukcja systemu kształcenia studentów zgodnie ze standardami obowiązującymi w zachodnich ośrodkach europejskich. Należy w tym miejscu zaznaczyć, że inicjatywy te przyczyniają się nie tylko do rekonstrukcji polskiego systemu szkolnictwa, lecz także sposobu konceptualizowania roli uniwersytetu we współczesnym świecie. Przyglądając się dyskusjom toczonym przy okazji prac nad ostatnią z ustaw dotyczących szkolnictwa wyższego, uznawaną przez Ministerstwo za dokument stanowiący przyczynek do najbardziej kompleksowej z - przeprowadzanych w tym sektorze po roku 1989 - reform, stwierdzić można, że tworzenie instytucji uniwersytetu „od nowa” wiąże się nieodmiennie z rytuałem odrzucenia socjalistycznego modelu uczelni wraz z całą jej infrastrukturą ${ }^{6}$ Pomysłodawcy reformy konieczność wprowadzenia zmian uzasadniają przy użyciu argumentów charakterystycznych dla okresu przemian ustrojowych. Mówi się np., że dotychczas obowiązujące modele zarządzania i finansowania uczelni, będące dziedzictwem systemu socjalistycznego, są nieelastyczne, zorientowane na podaż oraz pozbawione wewnętrznych mechanizmów ewaluacji i tym samym nie sprawdzają się w zmiennych warunkach rynkowych ${ }^{7}$. W świetle tych debat transformacja systemowa wydaje się być projektem wciąż niedokończonym.

Decyzja o gruntownej restrukturyzacji szkolnictwa wyższego w Polsce nie wynika dziś jednakże jedynie z potrzeby sfinalizowania długiego procesu transformacyjnego, lecz wiąże się z postępującą globalizacją oraz towarzyszącymi jej mechanizmami integracyjnymi operującymi w ramach Unii Europejskiej. Zmiany przyczynić się zatem mają do zwiększenia konkurencyjności polskich uczelni w Europie i na świecie oraz umocnić pozycję polskich naukowców w globalnym rynku wymiany wiedzy. Reforma uniwersytetu musi być zatem przeprowadzona zgodnie z ponadnarodowymi standardami i normami. Przekształcenia na poziomie

z czego 326 to liczba nowo powstałych szkół niepublicznych (dane na podstawie opracowania pt. Zmiany ilościowe w systemie szkolnictwa wyższego w III Rzeczypospolitej cz. 2, dostępnego na stronie internetowej: http://sawp.org.pl/index.php/biuletyny/biuletyn-nr-9/92-zmiany-ilociowe-wsystemie-szkolnictwa-wyszego-w-iii-rzeczypospolitej-cz2.html).

6 Ustawa weszła w życie dnia 1 października 2011 roku.

7 Por. Ministerstwo Nauki i Szkolnictwa Wyższego (2010). Założenia do nowelizacji ustawy - Prawo o szkolnictwie wyższym oraz ustawy o stopniach naukowych i tytule naukowym oraz o stopniach i tytule w zakresie sztuki, s. 13. 
lokalnym bez uwzględnienia owych globalnych trendów wydają się współcześnie niemożliwe.

Z uwagi na to, że zmiany zachodzące w polskich uczelniach są efektem światowych procesów globalizacyjnych, których transformacja systemowa jest pewnym szczególnym przypadkiem, tworzącym swoisty kulturowy, społeczny i historyczny kontekst, w zrozumieniu specyfiki tych przemian pomocna będzie koncepcja „globalnych asamblażów” (global asseblages) przedstawiona przez Stephena Colliera i Aihwę Ong w książce pt. Global Assemblages. Technology, Politics, and Ethics as Anthropological Problems (2005). Autorzy uznają, iż w świecie globalnych powiązań mamy do czynienia z przepływem ponadnarodowych idei, które artykułowane są w pewnych szczególnych sytuacjach, zwanych ,asamblażami”. Są to niestabilne, tymczasowe układy globalnych form i usytuowanych reżimów etycznych i politycznych (Collier, Ong, 2005, s. 4). W koncepcji przedstawionej przez Colliera i Ong znaczenia globalnych form „,nie są ograniczone przez kulturowe, społeczne czy ekonomiczne determinanty”. Jak zaznaczają autorzy, wyróżnia je to, iż potencjalnie mogą być one sytuowane w dowolnych przestrzeniach społecznych i kulturowych (ibidem). Ich badanie nie polega jednakże na próbie uchwycenia pewnych niezależnych od kontekstów typów idealnych, lecz na poszukiwaniu zespołów heterogenicznych elementów, poprzez które znaczenia ponadnarodowych form są artykułowane (ibidem, s. 4-5). Uwaga badaczy koncentruje się tym samym na specyficznych dla danego miejsca technologiach, $\mathrm{tj}$. sposobach wdrażania i realizowania globalnych form oraz reżimach prawdy i etyki, które zakorzenione w odmiennych politycznych i instytucjonalnych systemach regulują i determinują ich implementację. Proponowana przez antropologów koncepcja „globalnych asamblażów” zwraca uwagę na złożony charakter powiązań globalnych idei z przypadkowymi elementami, których nie można wprost sytuować w obrębie lokalności. Podkreśla ona jednocześnie dobrze znaną antropologii myśl, iż transfer ponadnarodowych form do specyficznych kontekstów kulturowych nigdy nie ma charakteru bezrefleksyjnego. Ich znaczenie zawsze podlega negocjacjom i rekonstrukcjom.

Przyjmując perspektywę Colliera i Ong, w badaniu zmian zachodzących na gruncie szkolnictwa wyższego, możemy zadać pytanie, z jakimi globalnymi formami mamy do czynienia oraz jakie polityczne technologie towarzyszą ich implementacji? W jaki sposób przyczynią się one do przemiany uniwersytetu i sposobu myślenia o jego zadaniach i celach? Z uwagi na to, że proces przekształcania uczelni zgodnie z założeniami najnowszej ustawy o szkolnictwie wyższym dopiero się rozpoczął, celem artykułu będzie przedstawienie możliwych skutków transformacji tej instytucji oraz ramy interpretacyjnej stosowanej do omawiania 
podobnych zagadnień. Artykuł ten stanowi zatem teoretyczne wprowadzenie do tematu.

Badacze i badaczki, którzy podejmują się analiz i interpretacji procesów transformacyjnych zachodzących w Europie Środkowo-Wschodniej oraz Chinach, podkreślają, że strukturalnym przekształceniom w dziedzinie gospodarki towarzyszy transfer wiedzy eksperckiej dotyczącej nie tylko sposobów funkcjonowania rozmaitych instytucji i organizacji, ale także kapitalistycznej koncepcji osoby (zob. np. Dunn, 2008). Zmiany te powiązane są z propagowaniem nowego typu myślenia o roli i znaczeniu instytucji, ich celach i zadaniach, a także z dążeniem do uformowania nowego rodzaju podmiotów społecznych. Transfer wiedzy dokonuje się zgodnie z kierunkiem Zachód-Wschód, centrum-(pół)peryferie. Mechanizm ten został dodatkowo wzmocniony po przystąpieniu Polski do Unii Europejskiej. Jedną z istotnych cech integracji europejskiej jest dążenie do przekształcenia lokalnych instytucji zgodnie ze standardami obowiązującymi na tym obszarze. Także w przypadku reform przeprowadzanych w sektorze szkolnictwa wyższego wiedza o zasadach, według których powinny funkcjonować uczelnie, dostarczana jest przez unijnych ekspertów i międzynarodowe organizacje, takie jak OECD i Bank Światowy, które przeprowadzają cykliczne ewaluacje polskiego szkolnictwa wyższego ${ }^{8}$. Jaką wizję uniwersytetu proponują zatem opiniodawcy?

By udzielić odpowiedzi na to pytanie, należy wskazać, że transformacja systemowa w Polsce miała miejsce w czasie, gdy w wielu krajach świata zaczęły być odczuwalne skutki nowego, realizowanego począwszy od lat 70 . XX wieku, neoliberalnego programu polityki gospodarczej wspieranego głównie przez polityków USA (Ronald Regan), Wielkiej Brytanii (Margaret Tatcher) oraz Chin (Deng Xiaoping $)^{9}$. Program ten zorientowany był przede wszystkim na zniesienie wszelkich barier uniemożliwiających swobodny przepływ kapitału międzynarodowego oraz powiązanie ze sobą lokalnych rynków finansowych, co skutkowało utworzeniem globalnej sieci wzajemnych zależności oraz ponadnarodowego sys-

8 Organizacja Współpracy Gospodarczej i Rozwoju (ang. Organization for Economic Co-operation and Development), por. Założenia do nowelizacji ustawy - Prawo o szkolnictwie wyższym oraz ustawy o stopniach naukowych i tytule naukowym oraz o stopniach i tytule w zakresie sztuki, s. 12.

9 Neoliberalizm rozumiany jest najczęściej jako nurt poglądów ekonomicznych, którego głównymi teoretykami i propagatorami byli ekonomiści Friedrich Von Hyek i Milton Friedman. Ich postulaty, począwszy od lat 70., zaczęli wcielać w życie przywódcy polityczni tacy jak: Augusto Pinochet (Chile), Ronald Regan (USA), Margaret Tatcher (Wielka Brytania) czy Deng Xaioping (Chiny). Reformy o charakterze neoliberalnym miały także miejsce w Polsce po roku 1989 (Plan Balcerowicza, wspierany przez „terapię szokową” Jeffreya Sachsa). Ogólnie rzecz biorąc, nurt ten wyznaje zasadę wolnego samoregulującego się rynku, w który państwo nie może interweniować. 
temu handlu. Wielu badaczy podejmujących tę problematykę uznaje, że przejście od keynesowskiego państwa dobrobytu do państwa neoliberalnego przyczyniło się do redefinicji związków łączących rynek i państwo oraz miało istotny wpływ na reorganizację instytucji prywatnych i publicznych ${ }^{10}$. Wśród cech dystynktywnych owego zwrotu w odniesieniu do przemian mających miejsce w obszarze szkolnictwa wyższego wymienia się najczęściej: zmniejszenie nakładów pieniężnych na naukę płynących z budżetu państwa, przy jednoczesnym wzroście zaangażowania sektora prywatnego w finansowanie badań, urynkowienie edukacji, czyli tworzenie sektora usług edukacyjnych, wywieranie przez rządzących nacisku na zacieśnianie współpracy pomiędzy nauką i gospodarką, wsparcie tych kierunków studiów, które mają duże znaczenie dla gospodarki przy jednoczesnym deprecjonowaniu kierunków humanistycznych, założenie, że nauka ma odpowiadać na potrzeby rynku, co łączy się z komercjalizacją badań naukowych i ich wyników itp. Podobne tendencje widoczne są także w obszarze szkolnictwa wyższego w Polsce. O ich istnieniu świadczyć może chociażby polityka Ministerstwa Nauki i Szkolnictwa Wyższego zorientowana na promowanie idei „gospodarki opartej na wiedzy” oraz wspieranie tzw. „kierunków zamawianych”.

Zmiany dokonujące się w europejskich ośrodkach akademickich, począwszy od lat 80 . XX wieku, są symptomem wyłonienia się nowego typu racjonalności, którą za Michelem Foucaultem określa się mianem neoliberalnego urządzania. Koncepcja „urządzania” (gouvernmentalité) posłużyła Foucaultowi do analizy biopolityki i zdefiniowana została jako: „zbiór instytucji, procedur, analiz, refleksji, kalkulacji i taktyk umożliwiających sprawowanie specyficznej i bardzo złożonej formy władzy nakierowanej przede wszystkim na populację, władzy opierającej się na ekonomii politycznej jako pewnej formie wiedzy i posługującej się zasadniczo urządzeniami bezpieczeństwa” (Foucault, 2010, s. 127). Jak zauważa francuski myśliciel, istotą neoliberalnych technologii rządzenia jest wykorzystanie modelu ekonomicznego do analiz „przedmiotów, obszarów działania i typów zachowań niebędących działaniami ani zachowaniami o charakterze rynkowym” (Foucault, 2011, s. 267). Tym samym dochodzi tu do zastosowania „modelu homo economicus do wszelkiego rodzaju działających podmiotów, nie tylko ekonomicznych" (Foucault, 2011, s. 268). Warto w tym miejscu zatem zaznaczyć, że Foucault rozumie neoliberalizm „nie jako teorię ekonomiczną lub jako ideologię polityczną, lecz jako specyficzną sztukę przewodzenia ludziom, która zorientowana jest na ludność jako nową postać polityczną i dysponuje ekonomią polityczną jako techniką

10 Na temat problemu dotyczącego zawłaszczania sfery publicznej przez dyskurs efektywnościowy toczy się w naukach społecznych szeroka dyskusja (por. Nawojczyk, 2014). 
interwencyjną” (Lemke, 2010, s. 55). Neoliberalnej logiki nie należy zatem - jak wskazuje Aihwa Ong - postrzegać w kategoriach uniwersalnej struktury czy systemu, lecz jako „przemieszczającą się technologię rządzenia, która wchodzi w interakcję z usytuowanymi zespołami elementów i wydarzeniami” (Ong, 2007, s. 5). Neoliberalne praktyki stanowią tym samym przykład „globalnej formy” rozprzestrzeniającej się w rozmaitych, czasem niewspółmiernych, kontekstach politycznych. W jaki sposób ten typ racjonalności rekonfiguruje instytucje? Jak neoliberalna logika zmienia myślenie o uniwersytecie?

Raz jeszcze warto podkreślić, że transformację systemową w Polsce należy rozumieć nie tylko w terminach odrzucenia koncepcji państwa kontrolującego sferę gospodarki, lecz również jako stopniową integrację z rynkiem europejskim i światowym. Proces ów - zdefiniowany poprzez neoliberalne urządzanie - wiąże się z wprowadzaniem odpowiednich regulacji, procedur i norm, dzięki którym towary wytwarzane w jednych miejscach mogą być porównywane z tymi produkowanymi gdzie indziej. Jest to zatem dążenie do stworzenia ponadnarodowej skali porównawczej, umożliwiającej klasyfikację dóbr oraz podmiotów. Zdaniem Elisabeth Dunn standardy wypracowane w Unii Europejskiej „stały się kluczowymi narzędziami «transformacji» posiadającymi moc dyscyplinowania i ujednolicania gospodarek, wytwórców i produktów” (Dunn, 2005, s. 183). Jak twierdzi badaczka, mamy tu do czynienia z procesem tworzenia „europejskiej «techostrefy» (technozone): homogenicznej pod kątem technologicznym przestrzeni, która rozpościera ponad geograficznymi i społecznymi podziałami, zapewniając w ten sposób swobodniejszy przepływ kapitału, ludzi i dóbr" (Dunn, 2005, s. 177). Zjawisko, o którym pisze Dunn, w pierwszej kolejności objęło organizacje sektora prywatnego, niemniej jednak w sposób systematyczny rozwiązania te wprowadzane są także w obrębie innych instytucji, w tym także w obszarze szkolnictwa wyższego.

Jednym z symptomów zwrotu neoliberalnego na gruncie europejskim była inicjatywa stworzenia Europejskiego Obszaru Szkolnictwa Wyższego, zakładająca działanie na rzecz wzmocnienia konkurencyjności uczelni europejskich względem amerykańskich i azjatyckich. Projekt ten, zwany procesem bolońskim, otworzył drogę do ujednolicenia standardów kształcenia w europejskich ośrodkach akademickich. Wskazał też kierunek rozwoju szkolnictwa wyższego w Polsce (podpisanie deklaracji nastąpiło w 1999 roku), tak, aby warunki kształcenia studentów krajowych i zagranicznych mogły stać się mierzalne i porównywalne. Proces boloński, którego zakończenie ogłoszono w 2011 roku, realizowano poprzez: „wprowadzenie systemu przejrzystych i porównywalnych stopni poprzez wdrożenie Suplementu do Dyplomu; przyjęcie systemu kształcenia opartego na 
dwóch/trzech poziomach kształcenia; powszechne stosowanie systemu punktów kredytowych (tj. ECTS - European Credit Transfer System); promocję mobilności studentów, nauczycieli akademickich, naukowców oraz personelu administracyjnego; promocję współpracy europejskiej w zakresie zwiększenia poziomu jakości szkolnictwa wyższego; promocję europejskiego wymiaru szkolnictwa wyższego, szczególnie w zakresie rozwoju zawodowego, mobilności oraz zintegrowanych programów nauczania, szkolenia i badań”"11.

Ustawa o szkolnictwie wyższym z 18 marca 2011 wpisuje się w założenia projektu bolońskiego, wzmacniając opisane powyżej procesy i mechanizmy. „Proponowane [tam] rozwiązania dotyczące zarówno systemu zarządzania szkołami wyższymi, modelu kariery akademickiej oraz praw i obowiązków studentów służyć mają też zmianie modelu kształcenia i ukierunkowaniu go na lepsze przygotowanie absolwentów, którzy posiadać będą nie tylko najnowszą, uniwersalną wiedzę, ale także umiejętności zgodne z wyzwaniami cywilizacyjnymi XXI wieku i potrzebami wynikającymi z rozwoju gospodarczego Polski”12.

Najbardziej doniosłe zmiany, jakie niesie ona ze sobą, dotyczą sposobów finansowania i zarządzania uczelnią oraz definiowania modelu kariery naukowej. Zgodnie z zamysłem pomysłodawców reformy jej celem jest przede wszystkim zwiększenie jakości kształcenia oraz innowacyjności polskich ośrodków akademickich i placówek badawczych, a także ich umiędzynarodowienie (zarówno poprzez stymulowanie wzrostu mobilności naukowców i studentów, jak i zachęcenie studentów zagranicznych do podjęcia nauki w Polsce). Ponadto wskazuje się także na konieczność pogłębienia współpracy naukowców z sektorem gospodarki i dostosowania oferty edukacyjnej uczelni do wymogów rynku pracy. Zadania te realizowane być mają poprzez: 1) dywersyfikację środków z budżetu państwa, w taki sposób by wzmocnić zasadę konkurencyjności pomiędzy placówkami akademickimi oraz naukowcami (przyznawanie dofinansowania na działalność badawczą i dydaktyczną głównie w drodze konkursowej); 2) transformację systemu zarządzania uczelnią, w taki sposób by docelowo zastąpić model „tradycyjnego zarządzania kolegialnego i elekcyjnego” przez nowoczesne modele menedżerskie; 3) uproszczenie ścieżki kariery naukowej, przy jednoczesnym wsparciu zasady konkurencyjności pomiędzy badaczami; 4) restrukturyzację programów nauczania, poprzez przyznanie uczelniom pełnej autonomii w tym zakresie 5) powołanie (lub przekształcenie) niezależnych komisji odpowiedzialnych za monitorowanie

11 http://www.nauka.gov.pl/proces-bolonski/tresc-do-artykulu-o-id-97,archiwum,1.html.

12 Założenia do nowelizacji ustawy - Prawo o szkolnictwie wyższym oraz ustawy o stopniach naukowych i tytule naukowym oraz o stopniach i tytule w zakresie sztuki, s. 3. 
efektów kształcenia i stopnia współpracy uczelni z podmiotami społeczno-gospodarczymi (Polska Komisja Akredytacyjna), jakości działalności naukowej placówek akademickich i badawczych (Komitet Ewaluacji Jednostek Naukowych), a także indywidualnej kariery naukowej (Centralna Komisja ds. Stopni i Tytułów).

Proces transformacji uniwersytetu zgodnie z neoliberalną logiką wiąże się przede wszystkim z działaniami na rzecz ujednolicenia standardów kształcenia w krajach członkowskich Unii. Zgodnie z deklaracją bolońską obejmują one stworzenie transparentnych i obiektywnych systemów oceny studentów, pracowników naukowych, poszczególnych instytutów, wydziałów oraz uniwersytetów, dzięki którym możliwe będzie skonstruowanie perspektywy porównawczej pozwalającej na zestawienie osiągnięć, kwalifikacji, programów i technik nauczania. Takiej standaryzacji służyć ma przyjęcie metod ewaluacji wykładanych przedmiotów przy pomocy punktów ECTS, stworzenie systemu parametryzacji jednostek naukowych, ujednolicenie dyplomów czy wprowadzenie krajowych ram kwalifikacji. Niniejsze systemy oceny jakości pracy instytucji i ich pracowników wymagają jednocześnie stworzenia odpowiednich mechanizmów kontroli wspierających realizację reform.

Badacze, którzy śledzą przekształcenia zachodzące w obrębie rozmaitych instytucji i organizacji, określają owe mechanizmy mianem „reżimów rozliczalności” (regimes of accountability) lub „ideologii rozliczalności”, wskazując w ten sposób zarówno na ich ekonomiczny, jak i moralny charakter ${ }^{13}$. Zgodnie z neoliberalną logiką zarządzanie podmiotami nie ma charakteru bezpośredniego, lecz zorientowane jest na generowanie „ekonomicznych bodźców, które będą wywoływać pożądane zachowania” (Kipnis, 2008, s. 279). Ma to na celu stworzenie podmiotów, które będą czuły się odpowiedzialne nie tyle wobec zwierzchników, ile wobec siebie. Władza nie oddziałuje tu zatem poprzez nakazy i kontrolę, lecz przy pomocy opartych na kalkulacji wyborów podejmowanych przez wolnych - z formalnego punktu widzenia - „aktorów” (Kipnis, 2008, s. 279). Strategia neoliberalnego rządzenia cechuje się zatem tym, że jednostki, dyscyplinując same siebie, stają się podmiotami rozliczalnymi, odpowiedzialnymi, elastycznymi i przedsiębiorczymi.

Włączenie polskiego szkolnictwa wyższego do globalnej sieci wymiany wiedzy, studentów i naukowców łączy się z koniecznością realizacji ponadnarodowych wytycznych regulujących sposób funkcjonowania instytucji oraz podmiotów, a także utworzenia odpowiednich organizacji, które będą czuwały nad ich implementacją. Pierwszą instytucją, która powstała w Polsce w celu kontrolowania

13 Posiłkuję w tym miejscu tłumaczeniem Przemysława Sadury, które pochodzi z książki E. Dunn (2008), s. 44. 
jakości kształcenia w ośrodkach akademickich, jest Polska Komisja Akredytacyjna, powołana pod nazwą Państwowej Komisji Akredytacyjnej, na mocy ustawy z dnia 20 lipca 2001 roku. Podstawowym jej celem jest wspomaganie „polskich uczelni publicznych i niepublicznych w budowaniu standardów edukacyjnych na miarę najlepszych wzorców obowiązujących w europejskiej i globalnej przestrzeni akademickiej”. „Polska Komisja Akredytacyjna realizuje swoją misję poprzez dokonywanie obligatoryjnych ocen jakości kształcenia oraz formułowanie opinii o wnioskach dotyczących uprawnień uczelni do prowadzenia studiów"14. Warto zwrócić uwagę na to, iż w wyniku działań reformatorskich ostatnich lat podobnych organów dyscyplinujących jest znacznie więcej. W 2010 roku powołany został Komitet Ewaluacji Jednostek, którego zadaniem będzie dokonywanie oceny jednostek naukowych (zgodnie z czterostopniową skalą: „A+ - poziom wiodący w skali kraju, A - poziom bardzo dobry, B - poziom akceptowalny z rekomendacją wzmocnienia działalności naukowej oraz C - poziom niezadowalający”15). W 2011 roku utworzono również Zespół ds. Dobrych Praktyk, który działać ma na rzecz „budowania takiego sposobu uprawiania nauki i funkcjonowania szkolnictwa wyższego, który pozbawiony będzie wszelkich przejawów nieprawidłowości”16. Podobną funkcję dyscyplinującą pełnią rozmaite wewnętrzne formy kontroli stosowane w poszczególnych ośrodkach akademickich. Są to np. rankingi osiągnięć czy ankiety.

Egzemplifikacje te ilustrują sposób działania neoliberalnych technologii rządzenia, które wykorzystują audyt do oceny działań podmiotów społecznych. Staje się on jednocześnie formą kontroli sprawowanej nad nimi. Jak zauważają Shore i Wright, praktyki audytu, które początkowo powiązane były głównie z procedurami analiz dokumentów finansowych, w szybkim czasie stały się integralnym elementem zarządzania instytucjami i podmiotami społecznymi (Shore, Wright, 2000, s. 59). W Wielkiej Brytanii przybrały one postać na tyle istotnego czynnika regulującego funkcjonowanie rozmaitych instytucji, iż brytyjscy antropolodzy zaczęli mówić o wyłaniających się pod wpływem zwrotu neoliberalnego „kulturach audytu”, które Marylin Strathern określa „kulturami zarządzania i rozliczalności”.

14 http://www.pka.edu.pl/misja.

15 http://www.nauka.gov.pl/komitet-ewaluacji-jednostek-naukowych-main/komitet-ewaluacjijednostek-naukowych,akcja,print.html.

16 http://www.nauka.gov.pl/dobre-praktyki-akademickie/zespol-ds-dobrych-praktyk-akade mickich.html 
Praktyki audytu wiążą się z wykształceniem się nowego języka, norm oraz etyki i polityki, które określane są przez badaczy mianem „rytuałów weryfikacji” (rituals of verification) (Power, 1996 za: Douglas, 1992) będących uosobieniem neoliberalnej racjonalności ${ }^{17}$. Ponieważ, tak jak wskazuje Foucault, jej istotną cechą jest przekształcanie praktyk społecznych i instytucji na wzór relacji rynkowych, reguły, na których opiera się wolny rynek, stają się zasadami organizującymi nie tylko sferę gospodarki, ale aktywność samego państwa i jego obywateli (Shore, Wright, 2000, s. 61). Nie chodzi tu tylko i wyłącznie o samo przeprowadzenie kontroli i czuwanie nad jakością procesów produkcyjnych (w tym procesu wytwarzania wiedzy). Praktyki audytu pełnią rolę mechanizmów regulujących działania podmiotów społecznych, a także nadają wiarygodność instytucjom, które wprowadzając europejskie standardy, stają się podatne na międzynarodową ocenę, a tym samym wiarygodne, dostępne i zrozumiałe.

Zdaniem Crisa Shora i Susan Wright techniki audytu „nie są nieszkodliwymi, neutralnymi, prawnymi i racjonalnymi praktykami, lecz instrumentami zarządzania i władzy, ucieleśniającymi nowego rodzaju racjonalność i moralność, wprowadzającymi nowe normy oraz nowy sposób definiowania profesjonalizmu”. Podkreślają oni także, że technologie te tworzą podmioty: „które same sobą zarządzają i poddają się audytowi” (Shore, Wright, 2000, s. 57). Tym samym audyt rozpatrywać można jako foucaultowską technikę rządzenia sobą, wyrastającą z koncepcji władzy sformułowanej przez francuskiego filozofa. Władzy nie definiuje on mianowicie w kategoriach wertykalnych jako narzędzia panowania klas dominujących, które „rozchodzi się z góry na dół, od centrum [...] do warstw najniższych” (Domańska, 2008, s. 26), lecz w kategoriach horyzontalnych. Chodzi tym samym o zwrócenie uwagi na fakt, iż podmioty internalizują normy i same siebie dyscyplinują, regulują własne działania, poddają się autokontroli, wspierając jednocześnie obowiązujący porządek społeczny. Audyt postrzegany jako technika rządzenia sobą staje się narzędziem konstytuującym nowe rozumienie profesjonalizmu, zawodowego i osobistego rozwoju. Zdaniem Elisabeth Dunn prowadzi to do konstruowania

17 Na szczególną uwagę w kontekście refleksji nad kulturami audytu zasługują badania Andrew B. Kipnisa, który zwraca uwagę na fakt, iż audyt nie jest praktyką ściśle i jednoznacznie związaną z neoliberalnym urządzaniem. Autor wskazuje, że na podobne formy kontroli wystawieni byli także obywatele krajów socjalistycznych. Na podstawie badań systemu edukacji przeprowadzonych w chińskiej prowincji Shandong podkreśla on, że praktyki audytu są tu utożsamiane z „rytuałem realizacji kwot produkcyjnych w dawnej socjalistycznej gospodarce planowej”, nie zaś z neoliberalnymi technologiami zarządzania. Kipnis uznaje jednocześnie, że w odniesieniu do reżimów prawdy znacznie bardziej trafna w tym kontekście jest nie krytyka neolibrealizmu, lecz krytyka scjentyzmu (Kipnis, 2008, s. 277). 
podmiotów przedsiębiorczych w odróżnieniu od podmiotów społecznie zakorzenionych (por. Dunn, 2008).

Procedury mierzenia osiągnięć podmiotów mają charakter formalny i policzalny. Scjentystyczne podejście powinno zapewnić bardziej obiektywne niż dotychczas i nie oparte na personalnych zależnościach metody oceny pracowników naukowych i studentów, w dalszej kolejności poszczególnych kierunków, wydziałów, jednostek badawczych i naukowych. Poziom aktywności naukowej badaczy, jakość czasopism oraz ośrodków akademickich można, zgodnie z założeniami tego podejścia, zmierzyć dzięki tworzonym do tego celu systemom punktacji. Aktorzy społeczni zostają w ten sposób - zgodnie z przewidywaniami Foucaulta przekształceni w aktorów ekonomicznych, którzy w celu produkcji wiedzy muszą dokonywać odpowiednich, skalkulowanych wyborów (np. odpowiedzieć sobie na pytanie: „czy bardziej opłaca mi się wydać monografię wartą x punktów czy artykuł w czasopiśmie naukowym obecnym w bazie ERIH?”).

Techniki audytu opisywane są przy pomocy apolitycznego, scjentystycznego języka, co sprawia, że „procedury oceny jawią się jako racjonalne, obiektywne, neutralne, konstruowane w oparciu o zasady skutecznych i wydajnych technik zarządzania” (Shore, Wright, 2000, s. 61). Mamy tu zatem do czynienia z rozbudową „scjentystycznej administracji” (Kipnis, 2008, s. 278), która wykorzystuje „numeryczny system pomiaru w celu ewaluacji” osiągnięć jednostek. Zarządzanie scjentystyczne zależne jest w znaczącym stopniu od policzalnych celów, a zatem takich, które można przełożyć na policzalne rezultaty. Zdaniem Shora i Wright procedury te - choć roszczą sobie prawo do bycia obiektywnymi - mają charakter normatywny. Brytyjscy badacze sądzą, że poprzez tworzenie rozmaitych list rankingowych (które podobnie do wniosków o przyznanie grantu czy cv możemy uznać za neoliberalne formy literackie) konfrontują ze sobą instytucje lub jednostki, wprowadzają podziały i reprodukują relacje władzy pomiędzy oceniającym i ocenianym (Shore, Wright, s. 2000).

Warto na koniec przyjrzeć się pokrótce projektowi, którego celem jest ujednolicenie standardów kształcenia w obrębie krajów objętych procesem bolońskim. W Polsce realizowany jest on przez Ministerstwo Nauki i Szkolnictwa Wyższego pod nazwą „Krajowe Ramy Kwalifikacji w szkolnictwie wyższym jako narzędzie poprawy jakości kształcenia”. Jak czytamy w dokumencie pt. Autonomia Programowa Uczelni. Ramy kwalifikacji dla szkolnictwa wyższego, krajowe ramy kwalifikacji (powstające w odwołaniu do europejskich ram kwalifikacji, są narzędziem służącym rozwojowi „wielkiej strategii budowy zintegrowanego obszaru szkolnictwa wyższego Europy”. Mają one na celu realizację dwóch, „z pozoru sprzecznych zadań”: „,jedno zachęca do podtrzymywania i rozwijania 
różnorodnych form, programów i instytucji kształcenia na poziomie wyższym; drugie postuluje stworzenie możliwości porównywania osiągnięć i kwalifikacji osób uczących się” (Kudrycka, 2010, s. 5).

Krajowe ramy kwalifikacji dla polskiego szkolnictwa wyższego pełnią także inną istotną rolę. Stanowią one mianowicie ważny instrument w procesie formowania nowych podmiotów społecznych, zgodnym z neoliberalną logiką. Efekty kształcenia opisywane we wspomnianym dokumencie obejmują nie tylko wiedzę, jaką musi zdobyć student. Poza umiejętnościami ogólnymi (różniącymi się w zależności od kierunku) winien on wykształcić także odpowiednie kompetencje społeczne i personalne. Np. student nauk humanistycznych: „Docenia tradycję i dziedzictwo kulturowe ludzkości oraz inicjuje i kieruje działaniami na rzecz zachowania dziedzictwa kulturowego regionu, kraju, Europy” (studia III stopnia); „Jest inicjatorem i kreatorem wydarzeń kulturalnych” (studia III stopnia); „Systematycznie uczestniczy w życiu kulturalnym, interesuje się aktualnymi wydarzeniami kulturalnymi, nowatorskimi formami wyrazu artystycznego, nowymi zjawiskami w sztuce” (studia II stopnia). Student nauk społecznych: „Jest przygotowany do tworzenia (współtworzenia) instytucji publicznych, organizacji gospodarczych, prywatnych i non profit w obszarze działalności społecznej, a także do podejmowania samodzielnej działalności w interesie publicznym lub własnym” (studia II stopnia); „Potrafi komunikować się z otoczeniem, w tym z osobami niebędącymi specjalistami w danej dziedzinie, przekazywać i bronić swoich poglądów, umie wypowiadać się w ważnych sprawach społecznych i światopoglądowych, posiada umiejętności retoryczne i erystyczne” (studia II stopnia). Student nauk ścisłych: „Rozumieją potrzebę ciągłego dokształcania się i odczuwają taką potrzebę, jako niezbędny warunek twórczego uczestnictwa w rozwoju uprawianej dziedziny” (studia III stopnia). Student podejmujący naukę na kierunkach przyrodniczych: „Posiada rozwinięte mechanizmy autoregulacyjne” (studia III stopnia); „Wykazuje przywództwo i przedsiębiorczość oraz świadomość pełnionej roli zawodowej” (studia II stopnia) (Kraśniewski, 2010, s. 29-33).

Warto zwrócić uwagę na to, że nowe zasady zawarte w krajowych ramach kwalifikacyjnych, zgodnie z którymi powinny być skonstruowane programy nauczania studentów, niosą ze sobą niebezpieczeństwo narzucenia tego, co za Slavojem Žižkiem określić można mianem Denkverbot, czyli fundamentalnego zakazu myślenia, który - zdaniem filozofa - cechuje współczesny liberalno-demokratyczny porządek (por. Žižek, 2006, s. 305-306). Jak przekonuje słoweński myśliciel, realizacja założeń systemu bolońskiego doprowadzi w konsekwencji do tego, iż uczelnie wyższe będą produkować ekspertów, których zadaniem będzie rozwiązywanie zdefiniowanych wcześniej problemów społecznych. Žižek twierdzi, 
że tego rodzaju zmiany wiążą się z osłabieniem publicznej funkcji rozumu, którego definicję przedstawił Immanuel Kant w artykule zatytułowanym Odpowiedź na pytanie: czym jest Oświecenie?. Kant przekonywał, że publiczny użytek z rozumu polega na rozbudzaniu wątpliwości, a zatem nie na próbie zaradzenia zdefiniowanym przez rozmaite instytucje problemom, lecz na refleksji nad samym sposobem ich definiowania (Žižek, 2010; por. Kant, 2005).

Podsumowując, uznać należy, że założenia reformy szkolnictwa wyższego zakorzenione są w neoliberalnym urządzaniu, będącym normatywnym typem racjonalności, która definiuje polityczne, etyczne i technologiczne działania. Neoliberalne urządzanie usiłuje - jak sądzi Elisabeth Dunn - zespolić nowe geograficzne przestrzenie i populacje nie przy pomocy jawnego przymusu, lecz poprzez ustanawianie licznych „«zestrojonych» regulacji, kodów i standardów” (Dunn, 2005, s. 175). Owe standardy, będące specyficznymi technologiami administracyjnymi, „określać mają nie tylko jakość produktu, lecz także poszczególne procesy produkcyjne i wytwarzanie danych, które można poddać ocenie” (ibidem). Ujednolicenie procesów wytwarzania wiedzy wymaga wprowadzenia praktyk dyscyplinujących, które regulują sposób funkcjonowania podmiotów społecznych. Ich zadaniem staje się od teraz sprawne zarządzanie sobą.

Co ciekawe, za standaryzacją rozmaitych procesów produkcyjnych (w tym także procesu produkcji wiedzy) na terenie Unii Europejskiej stoi przekonanie, podzielane implicite przez przywódców państw członkowskich, że każdy z obszarów zmaga się z takimi samymi problemami, których rozwiązaniu służą opracowywane regulacje (ibidem, s. 180). Niemniej jednak, jak podkreślają Stephen Collier i Aihwa Ong, choć globalne formy mają „szczególną zdolność do dekontekstualizacji i rekontekstualizacji, wyabstrahowania i przemieszczania się pomiędzy rozmaitymi społeczno-kulturowymi sytuacjami i sferami życia”, nie są one jednakże „niepowiązane ze społeczno-kulturowymi problemami”. Globalne formy charakteryzuje przede wszystkim to, że „zdolne są do asymilacji do nowych środowisk, kodowania heterogenicznych kontekstów i podmiotów w taki sposób, iż stają się one podatne na kontrolę i ewaluację” (Collier, Ong, 2005, s. 11).

Zmiany polskiego uniwersytetu zachodzące w wyniku reform wprowadzanych sukcesywnie na przestrzeni ostatnich dwóch dekad przyczyniają się do transformacji myślenia o roli i znaczeniu tej instytucji oraz wiedzy wytwarzanej i pozyskiwanej w jej ramach. Wpływają one w tym samym czasie na wytworzenie się nowego rodzaju podmiotów społecznych rozliczanych, odpowiedzialnych i przedsiębiorczych. Ponieważ proces ten nie jest jeszcze zakończony, nie sposób przewidzieć wszystkich jego skutków. Ponadto, jak pokazują badania kultur audytu, nie mamy tu do czynienia jedynie z biernymi postawami podmiotów 
poddających się przekształceniom, lecz aktywnymi praktykami oporu, które za Jamesem Scottem można określić mianem „oporu codziennego” (weapons of the weak $)^{18}$. Praktyki podejmowane przez instytucje, pracowników akademickich oraz studentów w obliczu wprowadzanych reform mogą więc stać się interesującym przedmiotem dalszych intensywnych badań, zaś przedstawiona w tym artykule rama interpretacyjna jest jednym z możliwych sposobów rozumienia przekształceń zachodzących w obszarze szkolnictwa wyższego.

\section{Literatura:}

Buchowski, M. (2011). Etnografia/etnologia polska w okresie „realnego socjalizmu”. Od niemarksistowskiej ortodoksji „etnografizmu” do postetnograficznego pluralizmu. LUD, 95, s. 13-43.

Kraśniewski, A. (2010). Wymagania dla obszarów kształcenia. W: Autonomia programowa uczelni. Ramy Kwalifikacji dla Szkolnictwa Wyższego (s. 22-76). Warszawa: Ministerstwo Nauki i Szkolnictwa Wyższego. Pobrane z: http://www.nauka.gov.pl/g2/ oryginal/2013_05/577acf803ab68698c4639ec62e77cf6a.pdf.

Douglas, M. (1992). Risk and Blame: Essays in Cultural Theory. London and New York: Routledge.

Domańska, E. (2008). O poznawczym uprzywilejowaniu ofiary (Uwagi metodologiczne). W: H. Gosk, B. Karwowska (red.), Nieobecność. Pominięcia i przemilczenia w narracjach XX wieku (s. 19-36). Warszawa: Dom Wydawniczy Elipsa.

Dunn, C.E. (2005). Standards and Person-Making in East Central Europe. W: A. Ong, S. Collier (red.), Global Assemblages. Technology, Politics, and Ethics as anthropological problems (s. 173-193). Oxford: Blackwell.

Dunn C.E., Sadura, P., Os, D. (2008). Prywatyzując Polskę. O bobofrutach, wielkim biznesie i restrukturyzacji pracy. Warszawa: Wydawnictwo Krytyki Politycznej.

Foucault, M. (2000). Historia seksualności, Warszawa: Czytelnik.

Foucault, M. (2010). Bezpieczeństwo, terytorium, populacja. Warszawa: PWN.

Foucault, M. (2011). Narodziny biopolityki. Warszawa: PWN.

Kant, I. (2005). Odpowiedź na pytanie: czym jest oświecenie? W: M. Żelazny (oprac.), I. Kant. Rozprawy z filozofii historii (s. 44-49). Kęty: Wydawnictwo Antyk.

Kipnis, B.A. (2008). Audit cultures: Neoliberal governmentality, socialist legacy, or technologies of governing? American Ethnologist, 35 (2), s. 275-289.

Lemke, T. (2010). Biopolityka. Warszawa: Sic!

Nawojczyk, M. (2014). What Money can't buy - nieodbyta debata. Kultura i Edukacja, 4 (104), s. 107-119. DOI 10.15804/kie.2014.04.08.

Ong, A. (2007). Boundary crossings. Neoliberalism as a mobile technology. Transactions of the Institute of British Geographers, 32 (1), s. 3-8.

Ong, A., Collier, J.S. (2005). Global Assemblages, Anthropological Problems. W: A. Ong,

18 Korzystam w tym miejscu z tłumaczenia M. Buchowskiego (zob. Buchowski, 2011, s. 19). 
S. Collier (red.), Global Assemblages. Technology, Politics, and Ethics as anthropological problems (s. 3-21). Oxford: Blackwell.

Power, M. (1996). Making Things Auditable. Accounting, Organizations and Society, 21, s. 289-315.

Scott, J. (1985). Weapons of the Weak: Everyday Forms of Peasant Resistance. New Haven, London: Yale University Press.

Shore, C., Wright, S. (2000). Coercive accountability: the rise of audit culture in higher education. W: M. Strathern (red.), Anthropological studies in accountability, ethics and the academy (s. 57-89). London: Routledge.

Žižek, S. (2006). Rewolucja u bram, Pisma Lenina z roku 1917. Warszawa: Wydawnictwo Krytyki Politycznej.

Žižek, S. (2010). A Permanent Economic Emergency. New Left Review, 64. Pobrane z: http://newleftreview.org/II/64/slavoj-zizek-a-permanent-economic-emergency. 